Artikel Penelitian

\title{
Kajian Karakteristik Beras Analog Berbahan Dasar Tepung dan Pati Ubi Ungu (Ipomea batatas)
}

\section{Study Characteristics of Analog Rice Made from Purple Sweet Potato (Ipomea batatas) Flour and Starch}

Noer Abyor Handayani", Heri Cahyono, Wiwit Arum, Indro Sumantri, Purwanto, Danny Soetrisnanto

Departemen Teknik Kimia, Fakultas Teknik, Universitas Diponegoro, Semarang

*Korespondensi dengan penulis (nora@undip.ac.id)

Artikel ini dikirim pada tanggal 20 Juni 2016 dan dinyatakan diterima tanggal 29 November 2016. Artikel ini juga dipublikasi secara online melalui www.jatp.ift.or.id. Hak cipta dilindungi undang-undang. Dilarang diperbanyak untuk tujuan komersial.

Diproduksi oleh Indonesian Food Technologists $@ ~(@ 2017$

\begin{abstract}
Abstrak
Beras analog merupakan beras tiruan yang terbuat dari bahan-bahan seperti umbi-umbian dan serealia. Ubi ungu (Ipomea batatas) adalah salah satu potensi lokal pangan yang layak dikembangkan sebagai bahan baku beras analog. Penelitian ini bertujuan untuk mengkaji pengaruh perbandingan komposisi tepung pati ubi ungu terhadap nilai gizi, sifat fisikokimia, sifat hedonik beras analog dibandingkan dengan beras padi, serta menentukan komposisi bahan baku terbaik dari beras analog ubi ungu. Penelitian ini terdiri dari 3 tahapan utama, yaitu tahap pembuatan tepung dan pati ubi ungu, tahap fortifikasi yang dilakukan bersamaan dengan proses pembuatan beras analog, serta tahap analisis hasil. Penelitian ini menggunakan variasi komposisi tepung dan pati ubi ungu sebesar 100:0 (A); 90:10 (B); 80:20 (C); 70:30 (D); 60:40 (E) dengan basis 100 gram. Beras Delangu digunakan sebagai variabel kontrol dalam penelitian ini. Hasil penelitian menunjukkan bahwa semakin tinggi komposisi pati dalam beras analog ubi ungu, maka kandungan amilosa meningkat, tekstur beras semakin keras dan tidak mudah rapuh, daya rehidrasi tinggi, dan densitas kamba rendah. Beras analog dengan komposisi $80 \%$ tepung dan $20 \%$ pati (kode C) merupakan produk yang paling disukai oleh panelis. Produk ini memiliki rasa, tekstur, dan kenampakan yang menyerupai beras pada umumnya. Beras analog kode C kaya akan kandungan protein 6,7337\%, kadar amilosa $15,56 \%$, nilai densitas kamba $0,638 \mathrm{~g} / \mathrm{ml}$ dan daya rehidrasi sebesar $1,5 \mathrm{ml} / \mathrm{g}$. Nilai gizi, sifat fisikokimia dan sifat hedonik beras analog memiliki karakteristik yang menyerupai beras Delangu. Berdasarkan beberapa parameter, beras analog memiliki keunggulan dibandingkan beras Delangu.
\end{abstract}

Kata kunci: beras analog, ubi ungu, tepung ubi ungu, pati ubi ungu, sifat fisikokimia

\section{Abstract}

Analog rice is artificial rice made from materials such as tubers and cereals. Purple sweet potato (Ipomea batatas) is one of the local potential to adequate food as a raw material of analog rice. This study aimed to assess the effect of sweet potato flour and starch to the nutritional value, physicochemical properties, hedonic properties compared with the commercial rice "Delangu", as well as determining the composition of the best raw materials from analog sweet purple rice. The study consists of three main stages, production of sweet potatoes flour and starch, fortification stage was carried out simultaneously with the process of making rice analog, as well as the results of the analysis phase. Composition of purple sweet potato flour and starch were used to produce analog rice, such as 100: $0(A) ; 90: 10(B) ; 80: 20(C) ; 70: 30(D) ; 60: 40(E)$ on the basis of 100 grams. Rice "Delangu" used as control variables in this study. The results showed that the higher composition of starch, the amylose content will increase, the texture of the rice is getting harder and not easily fragile, capacity rehydration is increasing, and low bulk density. Rice analog with a composition of $80 \%$ flour and $20 \%$ starch (code $\mathrm{C}$ ) is a preferred product by the panelists. This product has the taste, texture, and appearance that resembles rice in general. Analog rice code $C$ rich protein content of $6.7337 \%, 15.56 \%$ amylose content, Kamba density value of $0.638 \mathrm{~g} / \mathrm{ml}$ and rehydration power of $1.5 \mathrm{ml} / \mathrm{g}$. Nutritional value, physicochemical properties and hedonic properties of analog rice has characteristics that resemble "Delangu". Based on several parameters, analog rice has advantages over rice "Delangu".

Keywords: analog rice, purple sweet potato, sweet potato flour, sweet potato starch, psychochemical properties

\section{Pendahuluan}

Beras merupakan makanan pokok bagi masyarakat di Indonesia, namun meningkatnya kebutuhan komoditas beras tidak diimbangi dengan produksi beras dalam negeri, sehingga Pemerintah terpaksa melakukan impor beras untuk memenuhi permintaan masyarakat (Zaeroni and Rustariyuni, 2016). Diversifikasi produk pangan menyerupai beras merupakan salah satu alternatif solusi yang dapat ditawarkan kepada masyarakat. Produk tersebut dapat mengandung nilai gizi yang lebih unggul bila dibandingkan dengan beras. Indonesia memiliki potensi keaneragaman sumber karbohidrat non beras cukup banyak, namun belum dimanfaatkan secara optimal (Samad, 2003). Ubi ungu (Ipomea batatas) merupakan salah satu potensi pangan alternatif yang layak untuk dikembangkan. Komposisi betakaroten dalam ubi ungu mencapai 15 kali lebih banyak dibandingkan dengan wortel serta memiliki 110-210 mg antosianin setiap 100 gram tepung (Handayani et al., 2014; Lila, 2004). 
Karbohidrat yang terdapat pada ubi jalar ungu termasuk karbohidrat kompleks dengan Glycemic Index (GI) 54 yang rendah, sehingga aman dikonsumsi penderita diabetes (Widyaningtyas and Susanto, 2014).

Beberapa penelitian mengenai beras analog telah dilakukan oleh Noviasari et al., 2013; Lumba, 2012; Herawati and Widowati, 2009. Kajian proses pembuatan dan karakteristik beras analog dari ubi jalar (Ipomea batatas) telah berhasil dilakukan (Herawati and Widowati, 2009). Noviasari et al., 2013 berhasil membuat beras analog dengan memanfaatkan jagung putih sebagai bahan baku. Lumba (2012) menggunakan tepung umbi daluga (Cyrtosperma merkusii (hassk) schott) dalam pembuatan beras analog (Lumba, 2012). Berdasarkan pengetahuan penulis, penelitian mengenai pembuatan beras analog dari kombinasi tepung ubi ungu dan pati ubi ungu belum pernah dilakukan.

Penelitian ini bertujuan untuk mengkaji pengaruh perbandingan komposisi tepung ubi ungu dan pati ubi ungu terhadap kandungan gizi, sifat fisikokimia, serta sifat organoleptik beras analog ubi ungu bila dibandingkan dengan beras padi. Komposisi bahan baku terbaik dari beras analog ubi ungu juga dibahas dalam artikel ini.

\section{Materi dan Metode \\ Materi}

Bahan utama yang digunakan dalam penelitian ini adalah ubi ungu yang diperoleh dari Ambarawa. Air demineralisasi diperoleh dari hasil produksi Laboratorium Proses Departemen Teknik Kimia Universitas Diponegoro

\section{Pembuatan Tepung Ubi Ungu}

Pembuatan tepung ubi ungu dilakukan menggunakan tahapan yang dikembangkan oleh Herawati dan Widowati (2009) dengan modifikasi. Tahapan-tahapan tersebut yaitu pengupasan dan pencucian ubi ungu, penyawutan atau pengirisan ubi hingga tipis agar proses pengeringan dapat berlangsung lebih cepat. Selanjutnya, sawut direndam dalam sodium bisulfit $0,3 \%$ selama 1 jam agar warna ubi ungu tetap terjaga. Sawut dikeringkan dalam oven dengan suhu $60^{\circ} \mathrm{C}$ selama 12 jam. Sawut yang sudah kering selanjutnya digiling menjadi tepung dan diayak dengan ayakan 80 mesh. Pembuatan pati ubi ungu dilakukan metode yang dikembangkan oleh Herawati dan Widowati (2009), yaitu menyikat ubi yang tidak dikupas, lalu diparut dan diaduk/diperas, kemudian dilakukan penyaringan dan pengendapan. Selanjutnya, endapan dikeringkan menggunakan oven dengan suhu $60^{\circ} \mathrm{C}$ sampai kering. Pati kemudian digiling dan diayak menggunakan ayakan 80 mesh.

\section{Pembuatan Beras Analog Ubi Ungu}

Pembuatan beras analog ubi ungu dilakukan dengan mengadopsi penelitian Sumardiono et al., (2014). Air sebanyak $100 \mathrm{ml}$ (perbandingan air dan tepung $1: 1$ ) dipanaskan hingga mencapai suhu $80^{\circ} \mathrm{C}$. Hasil campuran tepung dan pati sebanyak 100 gram.
Komposisi tepung dan pati ubi ungu diatur sedemikian rupa sesuai dengan variabel yang ditetapkan, seperti variasi A (100:0); B (90:10); C (80:20); D (70:30); E $(60: 40)$. Air yang telah dipanaskan ditambahkan kedalam campuran sambil dipanaskan kembali sedikit demi sedikit di atas kompor listrik. Pemasakan dilakukan sambil diaduk selama 20 menit. Sifat kimia yang dianalisis yaitu kadar lemak, kadar protein, kadar karbohidrat, kadar air, kadar abu, kadar serat kasar, dan kadar amilosa. Sedangkan, sifat fisika yang dianalisis adalah daya rehidrasi, tekstur (hardness), densitas kamba, dan SEM.

\section{Analisis proksimat}

Analisa proksimat dilakukan pada produk beras analog berbahan dasar ubi ungu. Analisis proksimat terdiri dari analisa lemak metode ekstraksi, analisis protein metode Kjeldahl, analisis kadar abu, analisis kadar air, serta analisis karbohidrat metode by difference menggunakan metode AOAC (2006)

\section{Analisis Lemak}

Analisis lemak dilakukan dengan menimbang 3 gram sampel berupa serbuk kering yang dibungkus dengan kertas saring. Selanjutnya, dimasukkan ke dalam alat ekstraksi soxhlet dan di atasnya diletakkan kondensor. Labu ekstraksi kemudian diisi dengan 350 $\mathrm{ml} n$-hexane dan dipanaskan menggunakan pemanas water bath. Proses ekstraksi lemak dilakukan selama 6 jam. Setelah selesai, kemudian kertas saring berisi sampel dikeluarkan dari extractor dan dikeringkan. Sampel dikeringkan dengan cara di oven dengan suhu $130^{\circ} \mathrm{C}$ selama 1 jam, kemudian sampel dalam kertas saring ditimbang (AOAC, 2006). Prosentasi lemak dapat diketahui dengan menghitung selisih berat total basah dan berat total kering dibagi dengan berat total basah dikurangi berat kertas saring. Berat total basah dan kering adalah berat sampel ditambah berat kertas saring sebelum dan sesudah dimasukkan oven.

\section{Analisis Protein dengan Metode Kjeldahl}

Sebanyak 10 gram sampel ditimbang, dimasukkan ke dalam lagu digester, selanjutnya ditambahkan 10 gram $\mathrm{Na}_{2} \mathrm{SO}_{4}$ anhidrit, 5 gram $\mathrm{CuSO}_{4} .5 \mathrm{H}_{2} \mathrm{O}$ dan $30 \mathrm{ml} \mathrm{H} \mathrm{SO}_{4} 98 \%$ (AOAC, 2006). Panaskan labu digester di atas kompor dengan posisi sedikit miring agar pemanasan merata, lakukan proses dekstruksi protein hingga larutan berwarna jernih atau hijau muda (hijau pucat). Dinginkan labu, tambahkan aquadest secukupnya, lalu masukkan ke dalam labu distilasi. Tambahkan 4 gram $\mathrm{Zn}$ untuk mencegah terjadinya bumping serta percikan. Selama proses distilasi, tambahkan $100 \mathrm{ml}$ larutan $\mathrm{NaOH} 5 \mathrm{~N}$, selanjutnya distilat ditampung dalam Erlenmeyer yang berisi asam boraks jenuh sebanyak $150 \mathrm{ml}$. Proses dilakukan sampai $\mathrm{NaOH}$ habis. Untuk menentukan kadar protein, titrasi distilat yang diperoleh menggunakan $\mathrm{HCl}$ yang telah distandardisasi terlebih dahulu. Prosentasi protein dapat diketahui dengan menghitung perkalian antara Volume bersih, $\mathrm{N} \mathrm{HCl}$, angka 14, dan angka 6,25 kemudian dibagi dengan 
berat sampel. Volume bersih adalah selisih volume sampel dengan volume blanko.

\section{Analisis Karbohidrat dengan Metode By Difference}

Analisis karbohidrat dilakukan menggunakan metode penghitungan kadar karbohidrat by difference (AOAC, 2006). Prosentasi karbohidrat dapat diketahui dengan menghitung selisih kadar total $100 \%$ dengan kadar protein, lemak, abu dan air.

\section{Analisis Kadar Abu}

Cawan porselin dipanaskan terlebih dahulu ke dalam oven, kemudian didinginkan dalam desikator hingga mencapai suhu ruangan. Selanjutnya, $3-5$ gram sampel ditimbang kemudian dibakar di dalam cawan porselin sampai tidak berasap dan diabukan dalam tanur suhu $550^{\circ} \mathrm{C}$ sampai sampel berubah menjadi abu atau mencapai berat konstan. Kemudian, didinginkan dalam desikator hingga mencapai suhu ruangan secara konstan dan ditimbang (AOAC, 2006). Prosentasi kadar abu dapat diketahui dengan membagi berat abu dengan berat sampel.

\section{Analisis Kadar Air}

Cawan kering kosong yang akan digunakan ditimbang terlebih dahulu. Sebanyak 3 gram sampel di letakkan diatas cawan, kemudian ditimbang beratnya. Pastikan oven telah panas dan siap untuk mengeringkan sampel, selanjutnya cawan dimasukkan ke dalam oven dengan suhu $130^{\circ} \mathrm{C}$ selama 1 jam. Setelah selesai dikeringkan, cawan dipindah ke dalam desikator. Cawan didinginkan sampai suhu konstan dan hingga berat sampel serta cawan tetap (AOAC, 2006). Prosentase air dapat diketahui dengan menghitung selisih berat total basah dan berat total kering dibagi dengan berat total basah dikurangi berat cawan. Berat total basah dan kering adalah berat sampel ditambah berat cawan sebelum dan sesudah dimasukkan oven.

\section{Analisis Kadar Serat}

Sampel sebanyak $5 \mathrm{~g}$ dimasukan kedalam erlenmeyer $500 \mathrm{ml}$ kemudian ditambahkan $100 \mathrm{ml}$ $\mathrm{H}_{2} \mathrm{SO}_{4} 0,325 \mathrm{~N}$ dan dididihkan selama kurang lebih 30 menit. Lalu ditambahkan lagi $50 \mathrm{ml} \mathrm{NaOH} \mathrm{1,25} \mathrm{N}$ dan dididihkan selama 30 menit. Dalam keadaan panas, sampel disaring dengan kertas Whatman No. 40 setelah diketahui bobot keringnya. Kertas saring yang digunakan, dicuci berturut-turut dengan air panas, 25 $\mathrm{ml} \mathrm{H}_{2} \mathrm{SO}_{4}$ dan etanol 95\%. Kemudian dikeringkan di dalam oven bersuhu $100-110^{\circ} \mathrm{C}$ sampai bobotnya konstan. Kertas saring didinginkan dalam desikator dan ditimbang (AOAC, 2006). Prosentase kadar serat dihitung dengan membagi berat endapan kering dengan berat sampel.

\section{Analisis kadar amilosa}

Prinsip pengukuran amilosa adalah berdasarkan pembentukan warna biru akibat reaksi amilosa dengan iod yang diukur dengan spektrofotometer pada panjang gelombang $620 \mathrm{~nm}$. Analisis amilosa terdiri dari 2 tahapan yaitu pembuatan kurva standard dan penetapan amilosa pada sampel.

\section{Pembuatan kurva standar}

Amilosa murni ditimbang sebanyak $40 \mathrm{mg}$, lalu dimasukkan kedalam labu takar $100 \mathrm{ml}$, lalu ditambahkan etanol $1 \mathrm{ml}$ dan $\mathrm{NaOH} 1 \mathrm{~N}$ sebanyak $9 \mathrm{ml}$. Larutan standar didiamkan selama 24 jam dan ditambahkan aquades hingga tanda tera. Larutan standar dipipet masing-masing sebanyak 1,2,3,4, dan 5 $\mathrm{ml}$ lalu dimasukkan kedalam labu takar $100 \mathrm{ml}$. masingmasing larutan ditambahkan asam asetat $1 \mathrm{~N}$ sebanyak $0,2,0,4,0,6,0,8$, dan $1 \mathrm{ml}$, lalu ditambahkan larutan iod sebanyak $2 \mathrm{ml}$. larutan ditambahkan aquades hingga tanda tera, dikocok lalu didiambkan selama 20 menit, lalu diukur intensitas warnanya dengan spektrofotometer pada panjang gelombang $620 \mathrm{~nm}$.

\section{Penetapan amilosa pada sampel}

Sampel beras analog yang telah dihaluskan dimasukkan kedalam labu ukur $100 \mathrm{ml}$ kemudian diberi $1 \mathrm{ml}$ etanol $95 \%$ dan $9 \mathrm{ml} \mathrm{NaOH} 1 \mathrm{~N}$. Iarutan dibiarkan selama 23 jam pada suhu kamar atau dipanaskan dalam penangas air bersuhu $100^{\circ} \mathrm{C}$ selama 10 menit dan didinginkan selama 1 jam. Larutan kemudian diencerkan dengan air suling menjadi $100 \mathrm{ml}$, dipipet sebanyak $5 \mathrm{ml}$ dimasukkan kedalam labu ukur $100 \mathrm{ml}$ yang berisis $60 \mathrm{ml}$ air, kemudian ditambahkan $1 \mathrm{ml}$ asam asetat $1 \mathrm{~N}$ dan $2 \mathrm{ml} \mathrm{I}_{2} 2 \%$ dan diencerkan sampai volume $100 \mathrm{ml}$. larutan dikocok dan didiamkan selama 20 menit, kemudian diukur absorbannya dengan spektrofotometer pada panjang gelombang $620 \mathrm{~nm}$.

\section{Analisis daya rehidrasi}

Sampel sebanyak 1 gram ditambah $10 \mathrm{ml}$ air dan diaduk, kemudian didiamkan selama 30 menit pada suhu kamar. Campuran tersebut kemudian dimasukkan dalam centrifuge dengan kecepatan 3500 rpm selama 30 menit. Daya rehidrasi dihitung dengan membagi selisih volume air mula-mula dengan volume supernatant dengan bobot sampel (Handayani et al., 2014).

\section{Analisis tekstur (hardness)}

Pengujian tekstur menggunakan alat Texture Profile Analysis (TPA). Parameter pada uji tekstur adalah hardness (tingkat kekerasan) dengan menggunakan kecepatan $0,5 \mathrm{~mm} / \mathrm{s}$ dengan nilai deformasi sebesar 0,2 $\mathrm{mm}$.

\section{Analisis densitas kamba}

Analisis densitas kamba dilakukan merujuk pada metode yang digunakan oleh Handayani et al. 2014 dengan kombinasi. Sampel dengan ukuran yang sama dimasukkan ke dalam gelas ukur hingga volume $10 \mathrm{ml}$ dan diketuk-ketuk sebanyak 25 kali. Kemudian, sampel tersebut ditimbang. Nilai densitas kamba dihitung dengan cara membagi berat sampel dengan volume sampel. 
Analisis SEM (Scanning Electron Microscopy)

Struktur morfologi beras analog ubi ungu dapat dilihat menggunakan Scanning Electron Microscopy (SEM) (S-4800 scanning electron micrograph, Hitachi High Technologies Corporation, Tokyo, Japan).

\section{Analisis Hedonik}

Satu per satu sampel diberikan kepada panelis untuk dicicipi. Setelah itu, panelis diminta untuk memberikan penilaian pada kolom kode sampel dengan cara memasukkan nomor (berdasarkan tingkat kesukaan). Nomor 1 digunakan untuk mengindentifikasikan rasa tidak enak, nomor 2 untuk rasa enak, dan nomor 3 untuk rasa sangat enak. Netralkan indra pengecap panelis dengan air putih setelah mencicipi satu sampel. Himbau panelis agar tidak membandingkan tingkat kesukaan antar sampel.

\section{Hasil dan Pembahasan}

Kandungan gizi beras analog ubi ungu

Kandungan nutrisi dari beras analog ubi ungu dapat dilihat dengan menggunakan analisis proksimat, seperti yang ditunjukkan oleh Tabel 1. Hasil analisis lemak menunjukkan bahwa semakin tinggi komposisi pati maka menginisiasi terjadinya interaksi pati dengan molekul asam lemak bebas, sehingga dapat menghasilkan kadar lemak yang tinggi (Prosky and Devries, 1992). Kandungan lemak pada beras analog ubi ungu $(1,1101 \%-1,1233 \%)$ masih dibawah beras Delangu. Kadar lemak ini masih lebih kecil dibandingkan beras analog pada penelitian yang dilakukan Noviasari et al. (2013), yaitu sebesar 1,20\% $1,96 \%$. Kandungan lemak yang rendah dapat mencegah beras analog menjadi tengik sehingga memiliki masa simpan yang lebih lama.
Total protein dalam beras dapat dilihat pada Tabel 1. Beras analog ubi ungu memiliki kadar protein 4,3395\% hingga 9,3470\%. Semakin tinggi komposisi pati dalam beras analog, maka kadar protein menjadi semakin rendah karena protein yang larut air sebagian ikut terbuang dalam proses pembuatan pati. Kadar protein tersebut lebih tinggi bila dibandingkan dengan beras Delangu sebesar 3,3563\%, serta lebih besar dibandingkan dengan beras analog ubi daluga $(0,66 \%)$ (Lumba, 2012). Hasil analisis kadar karbohidrat beras analog ubi ungu dapat dilihat pada Tabel 1. Karbohidrat dalam beras ubi ungu menyerupai kandungan karbohidrat pada beras Delangu dan beras analog umbi daluga (83\%) (Lumba, 2012). Kadar karbohidrat tertinggi terdapat pada sampel E yaitu sebesar $83,6659 \%$ dan terendah pada sampel A sebesar $72,9622 \%$.

Kadar abu menunjukkan jumlah mineral yang terdapat di dalam suatu bahan. Hasil analisis kadar abu pada beras analog ubi ungu berkisar antara 2,6231\% hingga 2,8216\% (Tabel 1). Beras Delangu memiliki kadar abu sebesar $3,0374 \%$ dan lebih rendah bila dibandingkan dengan beras analog ubi ungu. Tabel 1 menunjukkan bahwa kadar serat kasar beras analog ubi ungu adalah 1,2521\%-1,3367\%. Semakin tinggi kadar pati dalam komposisi beras analog ubi ungu, maka kadar serat kasar semakin tinggi. Hal ini karena adanya pati resisten yaitu jenis pati yang tidak tercerna (resisten) dalam saluran sistem pencernaan manusia. Kadar air beras analog ubi ungu (Tabel 1) berkisar antara $8,0497 \%$ hingga $13,9576 \%$. Kadar air ini telah mendekati kadar air Beras Delangu sebesar $11,8082 \%$. Angka kadar air yang aman untuk penyimpanan beras yaitu $<14 \%$, sehingga mampu mencegah pertumbuhan kapang yang sering hidup pada serealia/biji-bijian.

Tabel 1. Hasil Analisis Proksimat Beras Analog Ubi Ungu

\begin{tabular}{ccccccc}
\hline Sampel & Lemak (\%bb) & Protein $(\% \mathrm{bb})$ & $\begin{array}{c}\text { Air } \\
(\% \mathrm{bb})\end{array}$ & $\begin{array}{c}\text { Abu } \\
(\% \mathrm{bb})\end{array}$ & $\begin{array}{c}\text { Karbohidrat } \\
(\% \mathrm{ob})\end{array}$ & Serat Kasar $(\%)$ \\
\hline $\mathrm{A}$ & 1,1101 & 9,3470 & 13,9576 & 2,6231 & 72,9622 & 1,2521 \\
$\mathrm{C}$ & 1,1145 & 6,7337 & 10,3985 & 2,7769 & 78,9764 & 1,3365 \\
$\mathrm{E}$ & 1,1233 & 4,3395 & 8,0497 & 2,8216 & 83,6659 & 1,3367 \\
Beras & 1,3078 & 3,3563 & 11,8082 & 3,0374 & 80,4903 & 1,5063 \\
Delangu & & & & & & \\
\hline
\end{tabular}

Tabel 2. Hasil Analisis Kadar Amilosa Beras Analog Ubi Ungu

\begin{tabular}{cccc}
\hline \multirow{2}{*}{ Sampel } & \multicolumn{2}{c}{ Komposisi } & \multirow{2}{*}{ Kadar amilosa (\%) } \\
\hline A & Tepung (\%) & Pati (\%) & 10,65 \\
B & 100 & - & 13,90 \\
C & 90 & 10 & 15,56 \\
D & 80 & 20 & 16,40 \\
E & 70 & 30 & 20,39 \\
Beras Delangu & 60 & 40 & 25,13 \\
\hline
\end{tabular}

Tabel 3. Hasil Analisis Densitas Kamba Beras Analog Ubi Ungu

\begin{tabular}{cc}
\hline Beras & Densitas Kamba $(\mathrm{g} / \mathrm{ml})$ \\
\hline Sampel A & 0,486 \\
Sampel B & 0,464 \\
Sampel C & 0,638 \\
Sampel D & 0,598 \\
Sampel E & 0,514 \\
Beras Delangu & 0,810 \\
\hline
\end{tabular}


Pengaruh komposisi pati terhadap kadar amilosa beras analog ubi ungu

Amilosa adalah senyawa polimer glukosa yang memiliki rantai lurus dan tidak bercabang (Zhou et al., 2013). Amilosa merupakan faktor penting yang mempengaruhi kekuatan gel pati karena akan membentuk struktur bahan pangan menjadi keras setelah dingin (Fitriyanto and Putra, 2013). Kadar amilosa yang terkandung di dalam bahan baku pembuatan beras analog ubi ungu mempengaruhi sifat dari beras dan nasi yang dihasilkan, seperti tingkat kepulenan dan sifat fungsional (Noviasari et al., 2013). Kadar amilosa menentukan tekstur dari nasi yang dihasilkan, pera tidaknya nasi, pulen tidaknya nasi, cepat mengeras serta lekat atau tidaknya nasi. Semakin tinggi kadar amilosa yang terdapat pada beras, maka akan menghasilkan nasi dengan tingkat pera yang tinggi, begitu pula sebaliknya. Tabel 2 menunjukkan bahwa kadar amilosa beras analog ubi ungu berkisar antara 10,65\% - 20,39\%.

Semakin tinggi komposisi pati dalam beras analog, maka semakin tinggi kandungan amilosa, dan tekstur beras semakin pera atau keras. Berdasarkan klasifikasi kandungan amilosa, beras dibedakan menjadi tiga kelompok, yaitu kelompok amilosa rendah $(12,1 \%$ - 20,0\%), kelompok amilosa sedang (20\% $24 \%$ ), dan kelompok amilosa tinggi (>25\%) (Juliano, 1994). Beras analog ubi ungu merupakan beras dengan amilosa rendah. Beras yang mengandung amilosa rendah akan menghasilkan nasi yang pulen dan tekstur yang lunak (Budijanto dan Yuliyanti, 2002). Amilosa merupakan polimer dari gula sederhana dengan rantai lurus dan tidak bercabang. struktur tersebut menyebabkan amilosa terikat lebih kuat sehingga sulit tergelatinisasi dan sulit untuk dicerna (Rimbawan dan Siagian, 2004). Kadar amilosa yang rendah akan membuat nasi semakin mudah untuk dicerna.

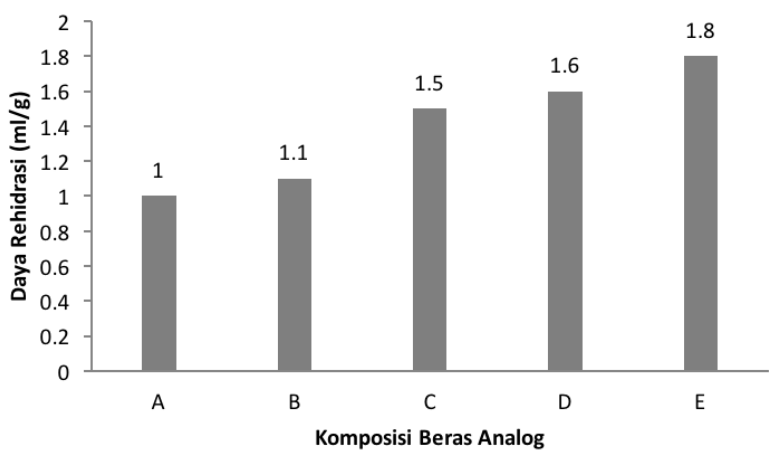

Figur 1. Hasil Analisis Daya Rehidrasi Beras Analog Ubi Ungu

\section{Daya rehidrasi beras analog ubi ungu}

Rehidrasi menunjukkan kemudahan penyerapan air dan kecepatan rekonstitusi (Nugroho et al., 2006). Daya rehidrasi yang tinggi memerlukan jumlah air yang lebih sedikit untuk proses rehidrasinya. Faktorfaktor yang mempengaruhi daya rehidrasi suatu produk instan adalah jenis bahan dasar dan komposisi kimianya (Slamet, 2011). Figur 1 menunjukkan nilai daya rehidrasi dari beras analog ubi ungu berkisar antara $1,0-1,8 \mathrm{ml} / \mathrm{g}$. Daya rehidrasi paling tinggi dimiliki oleh sampel $E$ sebesar $1,8 \mathrm{ml} / \mathrm{g}$ dengan komposisi pati sebesar $40 \%$. Komposisi pati yang tinggi dapat meningkatkan daya rehidrasi. Kemampuan pati untuk mengikat air dipengaruhi oleh gugus hidroksil bebas. Semakin banyak gugus hidroksil, maka semakin banyak jumlah air yang terikat dengan pati, sehingga daya rehidrasi menjadi semakin tinggi. Widowati et al. (2010) menyatakan bahwa bahan pangan dengan kadar pati yang tinggi akan semakin mudah menyerap air. Hal ini disebabkan oleh tersedianya molekul amilopektin yang bersifat reaktif terhadap molekul air, sehingga jumlah air yang terserap ke dalam bahan pangan semakin banyak.

\section{Analisis Densitas Kamba Beras Analog Ubi Ungu}

Densitas kamba adalah pengukuran berat jenis produk kering yang dihitung berdasarkan bobotnya dalam suatu wadah (Schutyser et al., 2015). Densitas kamba dipengaruhi oleh densitas padatan, geometri, ukuran, dan sifat permukaan dari partikel individunya (Fellows, 2002). Suatu bahan dinyatakan kamba apabila memiliki nilai densitas kamba yang rendah. Densitas kamba yang rendah (voluminous) menunjukkan bahwa dalam volume tertentu yang sama, produk tersedia dalam berat yang lebih sedikit dan menunjukkan kepadatan gizi yang rendah pula. Hal ini berarti bahwa semakin rendah nilai densitas kamba, maka bahan pangan tersebut akan cenderung lebih cepat memberi rasa kenyang, akan tetapi, asupan gizinya belum dapat terpenuhi (Handayani et al. 2014; Arifianti, 2012).

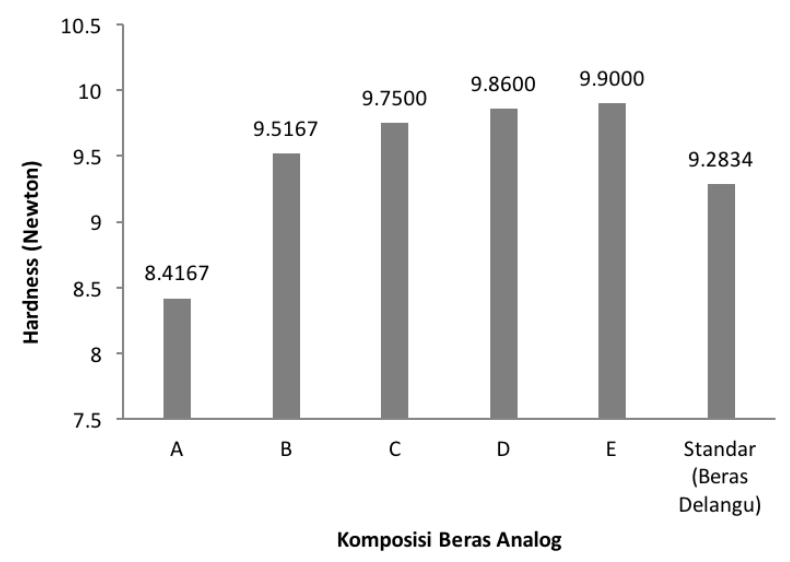

Figur 2. Hasil Analisis Fisik Tekstur (Hardness) Beras Analog Ubi Ungu

Tabel 3 menunjukkan nilai densitas kamba dari beras analog ubi ungu. Nilai densitas kamba beras analog pada berbagai komposisi $(0,464-0,598 \mathrm{~g} / \mathrm{ml})$ lebih rendah bila dibandingkan dengan beras Delangu $(0,810 \mathrm{~g} / \mathrm{ml})$. Beras analog ubi ungu memiliki berat yang lebih kecil dibandingkan beras Delangu pada volume yang sama.

Hasil analisis densitas kamba beras analog ubi ungu bertujuan untuk mengetahui volume dan porositas beras. Berdasarkan data yang tersaji di atas, beras 
analog sampel $\mathrm{C}$ memiliki densitas kamba yang lebih besar dibanding beras analog sampel lain. Hal ini menunjukkan bawa porositas dari beras analog tersebut lebih rendah, di mana porositas dari beras analog ini dipengaruhi oleh kandungan gizi beras analog maupun proses pembuatan yang meliputi pengeringan. Proses pengeringan membuat beras analog kehilangan air sehingga beras analog menjadi lebih poros.

Selama proses pemasakan beras, terjadi pengembangan atau ekspansi beras. Pengembangan atau ekspansi beras selama pemasakan akan meningkatkan volume nasi, tetapi menurunkan massa. Oleh karena itu, semakin tinggi tingkat ekspansi beras, akan menyebabkan densitas kamba semakin rendah (Noviasari et al., 2013). Dalam penelitian ini, beras analog ubi ungu sampel $\mathrm{C}$ memiliki densitas kamba yang lebih rendah dibanding beras Delangu. Densitas kamba yang tergolong rendah ini akan membuat konsumen menjadi cepat kenyang, namun asupan gizinya menjadi kurang (Handayani et al., 2014; Adzim et al., 2014).

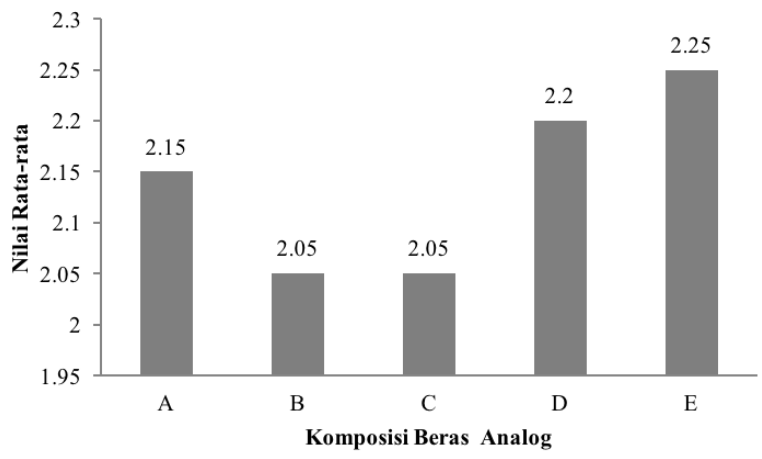

Figur 3. Hasil Nilai Rata-Rata Uji Hedonik Parameter Aroma

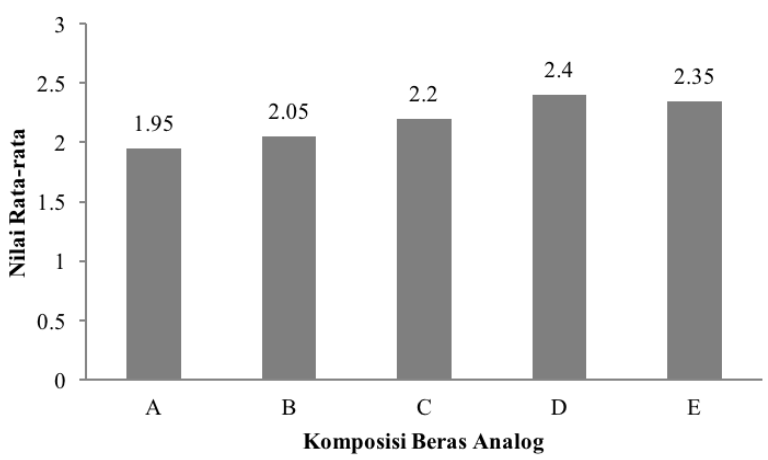

Figur 4. Hasil Nilai Rata-Rata Uji Hedonik Parameter Rasa

Karakteristik tekstur beras analog ubi ungu

Pengujian tekstur dilakukan menggunakan

Texture Profile Analysis (TPA). Hardness (tingkat kekerasan) merupakan salah satu parameter uji tekstur. Kekerasan (hardness) adalah gaya yang berupa tekanan atau tegangan yang diperlukan untuk merubah bentuk fisik bahan (Chen et al., 2012). Figur 2 memperlihatkan nilai tingkat kekerasan pada produk beras analog ubi ungu.

Nilai kekerasan beras ubi ungu pada berbagai komposisi berkisar antara 8,4167 Newton hingga 9,9
Newton. Sampel yang memiliki tekstur paling keras yaitu sampel E (9,9 Newton) sedangkan sampel dengan tekstur paling rapuh yaitu sampel $A$ sebesar 8,4167 Newton. Beras Delangu membutuhkan energi sebesar 9,28335 Newton untuk mengalami deformasi sebesar $0,2 \mathrm{~mm}$.

Figur 2 juga menunjukkan bahwa tingkat kekerasan beras analog ubi ungu pada sampel B,C,D,E lebih tinggi bila dibandingkan dengan beras Delangu. Parameter tingkat kekerasan berpengaruh sangat besar dalam beras analog karena akan menentukan konsistensi bentuk beras analog yang biasanya rawan pecah (hancur). Semakin tinggi kandungan pati pada komposisi beras analog menunjukkan tingkat kekerasan yang lebih tinggi dibandingkan dengan komposisi beras analog yang rendah pati, seperti yang ditunjukkan oleh Figur 2. Hal ini sesuai dengan fenomena yang telah dijelaskan sebelumnya pada pengaruh amilosa terhadap tekstur beras analog yang dihasilkan.

\section{Uji Hedonik Parameter Aroma}

Pada pengujian hedonik terhadap parameter aroma (Figur 3), beras analog terbaik terdapat pada sampel $A(2,15)$, $D(2,2)$, dan $E(2,25)$. Pada formula ini, dihasilkan aroma beras analog yang tidak begitu kuat, sedangkan formula lainnya cenderung beraroma ubi ungu yang sangat kuat. Pada umumnya, konsumen kurang menyukai aroma yang menyengat. Sedangkan, berdasarkan hasil analisis varian, diperoleh nilai $F$ hitung $(0,1286 \%)$ yang lebih kecil dibanding $\mathrm{F}$ tabel $5 \%$ $(2,71 \%)$ dan $\mathrm{F}$ tabel $1 \%(4,1 \%)$. Hal ini menunjukkan bahwa tidak ada perbedaan nyata pada tingkat $5 \%$ dan tidak ada beda nyata antar sampel pada tingkat $1 \%$. Perlakuan yang diberikan pada tiap sampel tidak memberikan perbedaan yang signifikan pada rasa beras analog ubi ungu.

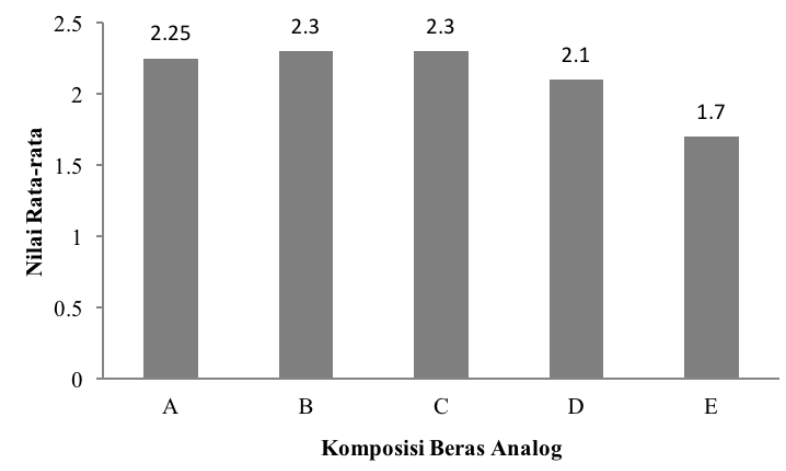

Figur 5. Hasil Nilai Rata-Rata Uji Hedonik Parameter Tekstur

Uji Hedonik Parameter Rasa

Pada pengujian hedonik terhadap parameter rasa (Figur 4), beras analog dengan nilai terbaik terdapat pada sampel C $(2,2)$, D $(2,4)$, dan E $(2,35)$. Penilaian panelis pada sampel tersebut dengan tingkat penerimaan enak menuju sangat enak dikarenakan beras analog pada formula ini memiliki rasa yang hambar sehingga mendekati rasa beras pada umumnya. Berdasarkan hasil analisis varian, diperoleh 
nilai $F$ hitung sebesar $0,95716 \%$ yang lebih kecil dibandingkan $\mathrm{F}$ Tabel $5 \%$ dan $\mathrm{F}$ Tabel 1\% berturut-turut $2,71 \%$ dan $4,1 \%$. Hal ini menunjukkan bahwa tidak terdapat perbedaan nyata antar sampel pada tingkat $5 \%$ dan $1 \%$. Perlakuan yang diberikan pada tiap sampel tidak memberikan perbedaan yang signifikan pada rasa beras analog ubi ungu.

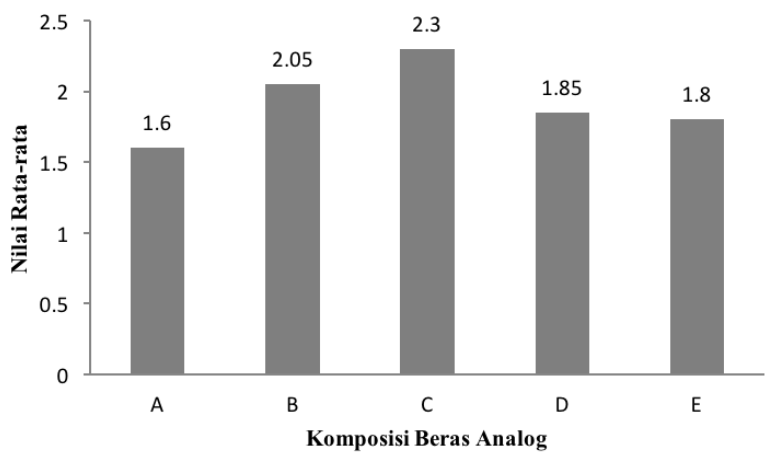

Figur 6. Hasil Nilai Rata-Rata Uji Hedonik Parameter Kenampakan

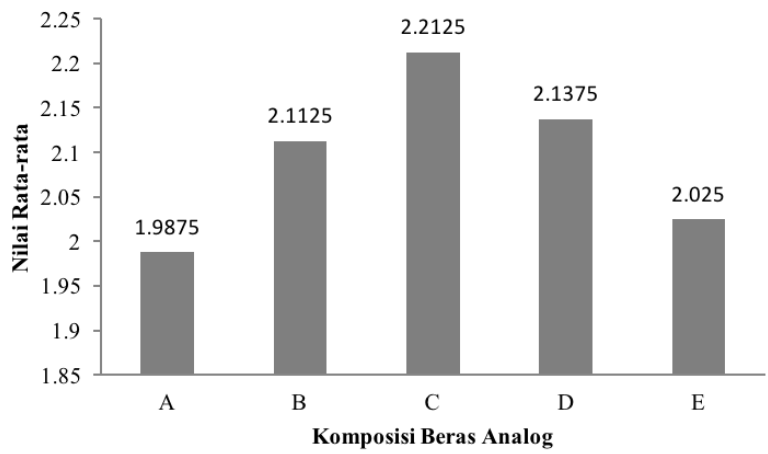

Figur 7. Hasil Nilai Rata-Rata Uji Hedonik Parameter Keseluruhan

\section{Uji Hedonik Parameter Tekstur}

Pada hasil pengujian hedonik beras analog terhadap parameter tekstur (Figur 5), diperoleh nilai terbaik yang terdapat pada sampel A $(2,25)$, B $(2,3)$, dan $C(2,3)$. Penilaian panelis terhadap tekstur beras analog terbaik dengan penerimaan enak menuju sangat enak. Perlakuan yang diberikan pada tiap sampel tidak memberikan perbedaan yang signifikan pada rasa beras analog ubi ungu. Pada umumnya, konsumen cenderung menyukai nasi yang tidak pera, namun juga tidak terlalu pulen. Formula beras analog pada sampel $\mathrm{A}, \mathrm{B}$, dan $\mathrm{C}$ menghasilkan nasi dengan tekstur yang mendekati nasi pada umumnya. Hasil analisis varian diperoleh nilai $\mathrm{F}$ hitung sebesar 1\% lebih kecil dibandingkan $\mathrm{F}$ Tabel 5\% dan $\mathrm{F}$ Tabel 1\% berturut-turut yaitu $2,71 \%$ dan $4,1 \%$. Hal ini menunjukkan bahwa tidak terdapat perbedaan nyata antar sampel pada tingkat $5 \%$ dan $1 \%$. Perlakuan yang diberikan kepada masing-masing sampel tidak memberikan perbedaan yang nyata pada tekstur beras analog ubi ungu.

\section{Uji Hedonik Parameter Kenampakan}

Pada hasil pengujian nasi dari beras analog ubi ungu terhadap parameter kenampakan (Figur 6), diperoleh sampel B $(2,05)$ dan $C(2,3)$ sebagai beras analog dengan nilai terbaik. Pada formula beras analog ini, dihasilkan kenampakan beras analog ubi ungu yang menyerupai bentuk dari beras biasa. Pengujian hedonik juga dilakukan menggunakan analisis varian. Berdasarkan hasil analisis varian, diperoleh nilai $F$ hitung sebesar $0,7435 \%$ lebih kecil dibandingkan $F$ tabel $5 \%$ dan $\mathrm{F}$ tabel $1 \%$ berturut-turut yaitu $2,71 \%$ dan $4,1 \%$. Hal ini menunjukkan bahwa tidak terdapat perbedaan nyata antar sampel pada tingkat 5\% dan $1 \%$. Perlakuan yang diberikan pada masing-masing sampel tidak memberikan perbedaan nyata pada kenampakan beras analog ubi ungu.

\section{Uji Hedonik Keseluruhan}

Berdasarkan nilai rata-rata hasil pengujian hedonik secara keseluruhan (Figur 7), diperoleh sampel C sebagai beras analog dengan nilai terbaik dari parameter aroma, rasa, tekstur, dan kenampakan. Penilaian secara keseluruhan dilakukan berdasarkan aroma, rasa, tekstur, dan kenampakan nasi dari beras analog ubi ungu. Pada sampel $\mathrm{C}$, beras analog memiliki rasa, tekstur, dan kenampakan yang menyerupai beras pada umumnya, walaupun masih beraroma ubi ungu. Kandungan amilosa beras analog sebesar 15,56\% termasuk ke dalam beras yang tidak pera dan tidak pulen pula. Sampel C memiliki kadar karbohidrat $(78,9764 \%)$ lebih kecil dibandingkan kadar karbohidrat pada beras Delangu, namun memiliki kadar protein yang lebih besar dibandingkan beras Delangu yaitu $6,7337 \%$ (Tabel 1).

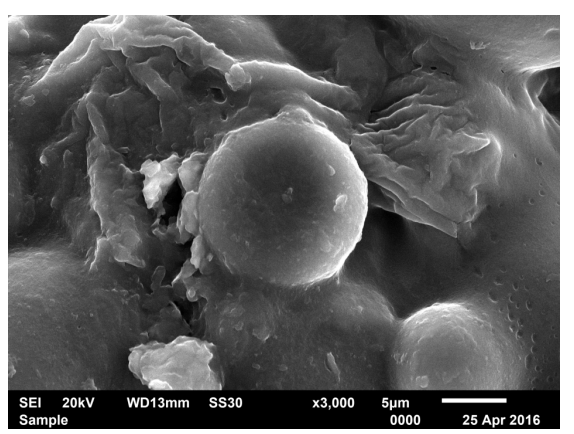

Figur 8. Hasil Analisis SEM Beras Analog Ubi Ungu Sampel C

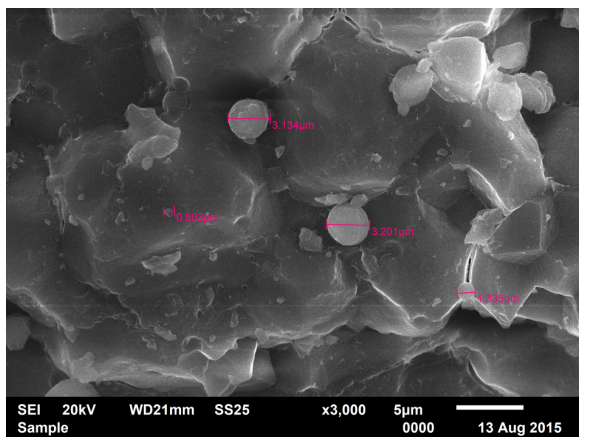

Figur 9. Hasil Analisis SEM Beras Delangu

\section{Analisis SEM (Scanning Electron Microscopy)}

Berdasarkan hasil uji hedonik keseluruhan (Figur 7), diperoleh bahwa komposisi beras analog terbaik terdapat pada sampel C. Sampel C (Figur 8) dan beras 
Delangu (Figur 9) dianalisis SEM guna mengetahui struktur mikroskopik dari keduanya.

\section{Kesimpulan}

Berdasarkan nilai rata-rata hasil hedonik secara keseluruhan, diperoleh sampel C (80\% tepung, 20\% pati) sebagai beras analog dengan nilai terbaik. Pada sampel ini, beras analog memiliki rasa, tekstur, dan kenampakan yang menyerupai beras pada umumnya, walaupun masih beraroma ubi ungu. Hasil analisis kimia menunjukan bahwa beras analog terbaik pada penelitian ini mengandung lemak $1,1145 \%$, protein $6,7337 \%$, air $10,3985 \%$, abu $2,7769 \%$, karbohidrat $78,9764 \%$, dan serat kasar 1,3365\%. Kandungan amilosa beras analog sebesar $15,56 \%$, sehingga termasuk dalam golongan beras beramilosa rendah. Hasil analisis fisik beras analog terbaik pada penelitian ini menunjukkan bahwa beras analog ubi ungu terbaik memiliki daya rehidrasi 1,5 , tekstur (kekerasan) sebesar 9,75 Newton, dan densitas kamba 0,638 gr/ml.

\section{Ucapan Terimakasih}

Tim Peneliti mengucapkan terima kasih kepada Fakultas Teknik Universitas Diponegoro yang telah membiayai penelitian ini melalui Program Penelitian Dasar Tahun 2016 berdasarkan SK Rektor Universitas Diponegoro Nomor: 563/UN7.P/HK/2016.

\section{Daftar Pustaka}

Adzim, M.F., Putri, S.K., Handayani, N.A. 2014. Fortifikasi $\mathrm{FeSO}_{4}$ pada tepung ubi ungu (ipomoea batatas I.) sebagai bahan dasar pembuatan bubur bayi instan. Prosiding Seminar Rekayasa Kimia dan Proses.

Arifianti, A., Katri, A. R. B., Rachmawanti, A. D., Riyadi, P.N.H. 2012. Karakterisasi bubur bayi instan berbahan dasar tepung millet (Panicum sp) dan tepung beras hitam (Oryza sativa L. Japonica) dengan flavor alami pisang ambon (Musa paradisiaca var. sapientum). Jurnal Teknosains Pangan, 1(1), 1-8.

AOAC (Association of Official Analytical Chemist). 2006. Official Methods of Analytical of The Association of Official Analytical Chemist. Washington, DC: AOAC.

Budijanto, S., Yuliyanti. 2012. Studi persiapan tepung sorgum (Sorghum bicolor $L$. Moench) dan aplikasinya pada pembuatan beras analog. Jurnal Teknologi Pertanian, 13, 177-186.

Chen, J., Khandelwal, N., Liu, Z., Funami, T. 2013. Influences of food hardness on the particle size distribution of food boluses. Archives of oral biology, 58(3), 293-298.

Fellows, P.J. 2009. Food processing technology: principles and practice. Elsevier.

Fitriyanto, M., Putra, S.R. 2013. Karakterisasi beras buatan (artificial rice) dari campuran tepung sagu (Metroxylon sp.) dan tepung kacang hijau. Jurnal Sains dan Seni Pomits, 2, 1-3.

Handayani, N. A., Santosa, H., Kusumayanti, H. 2014. Fortifikasi inorganik zink pada tepung ubi jalar ungu sebagai bahan baku bubur bayi instan. Reaktor, 15(2), 111-116
Herawati, H., Widowati, S. 2009. Karakteristik beras mutiara dari ubi jalar (Ipomea batatas). Buletin Teknologi Pascapanen Pertanian Vol. 5 : 37-44.

Juliano, B.O., Hicks, P.A., Ton That, T. 1994. Utilization of rice functional properties to produce rice food products with modern processing technologies. International Rice Commission Newsletter (FAO), 39, 163-178.

Lila, M. A. 2004. Anthocyanins and human health: an in vitro investigative approach. Journal of Biomedicine and Biotechnology, 5, 306-313.

Lumba, R., Mamuaja, C.F., Djarkasi, G.S.S., Sumual, M.F. 2012. Kajian pembuatan beras analog berbasis tepung umbi daluga (Cyrtosperma merkusii (Hassk) Schott). Jurnal Jurusan Teknologi Pertanian. Fakultas Pertanian Universitas Sam Ratulangi, 1-13

Prosky, L., DeVries, J.W. 1992. Controlling dietary fiber in food products. New York: Van Nostrand Reinhold

Noviasari, S., Kusnandar, F., Budijanto, S. 2013. Pengembangan beras analog dengan memanfaatkan jagung putih. Jurnal Teknologi dan Industri Pangan, 24(2), 194-200.

Nugroho, E.S., Tamaroh, S., Setyowati, A. 2006. Pengaruh konsentrasi gum arab dan dekstrin terhadap sifat fisik dan tingkat kesukaan temulawak (Curcuma Xanthorhiza Roxb) Madu Instan, LOGIKA, 3(2), 78-86.

Rimbawan dan Siagian, A. 2004. Indeks Glikemik Pangan. Penebar Swadaya.

Samad, Y. 2003. Pembuatan beras tiruan (artificial rice) dengan bahan baku ubi kayu dan sagu. Jurnal Sains dan Teknologi, 2, 36-40.

Slamet, A. 2011. Fortifikasi Tepung Wortel dalam Pembuatan Bubur Instan untuk Peningkatan Provitamin A. Agrointek, 5(1), 1-8.

Schutyser, M.A.I., Qiu, J., Almeida-Rivera, C., Khalloufi, S., van Dalen, G., Benali., M. 2015. Porosity Predictions of Processed Food Materials using Experimental Data of Bulk Density and Volume Shrinkage. In Proceedings Eurodrying conference.

Sumardiono, S., Pudjihastuti, I., Poerwoprajitno, A.R., Suswadi, M.S. 2014. Physichocemical Properties of Analog Rice from Composite Flour: Cassava, Green Bean and Hanjeli. World Applied Sciences Journal, 32(6), 1140-1146.

Widowati, S., Nurjanah, R., Amrinola, W. 2010. Proses pembuatan dan karakterisasi nasi sorgum instan. Prosiding Pekan Serealia Nasional, 35-48

Widyaningtyas, M., Susanto, W.H., 2014. Pengaruh jenis dan konsentrasi hidrokoloid (carboxy methyl cellulose, xanthan gum, dan karagenan) terhadap karakteristik mie kering berbasis pasta ubi jalar varietas ase kuning. Jurnal Pangan dan Agroindustri, 3(2), 417-423.

Zaeroni, R., Rustariyuni, S.D. 2016. Pengaruh produksi beras, konsumsi beras dan cadangan devisa terhadap impor beras di Indonesia. E-Jurnal Ekonomi Pembangunan Universitas Udayana, 5(9), 993-110

Zhou, X., Wang, R., Zhang, Y., Yoo, S. H., Lim, S.T. 2013. Effects of amylose chain length and heat treatment on amylose-glycerol monocaprate complex formation. Carbohydrate polymers, 95(1), 227-232. 